\title{
НАНОКОМПОЗИТ С АНТИБАКТЕРИАЛЬНЫМИ СВОЙСТВАМИ НА ОСНОВЕ МОДИФИЦИРОВАННОГО ХЛОПКОВОГО ВОЛОКНА
}

\author{
Р.М. Алосманов, А.А. Шукюров, И.А. Буният-заде \\ Химический факультет, Бакинский Государственный Университет, \\ AZ 1148, Азербайджан, Баку, ул. 3.Халилова 23.
}

DOI: 10.19163/MedChemRussia2021-2021-459

E-mail: r_alosmanov@rambler.ru

Химическая модификация природных и синтетических полимеров один из самых эффективных методов направленного полученияновых композиционных материалов, обладающих, в ряде случаев, целым комплексом полезных свойств [1]. Целлюлоза - самый распространенный полимер в природе, по количеству намного превосходящий промышленный выпуск синтетических полимеров, и не требующий сложных технологий полимеризации мономеров, поскольку источником ее получения выступают растения, внутренняя структура которых, в значительной степени построена из целлюлозы и сформирована в результате их естественного роста [2].

В настоящей работе представлена модификация хлопкового волокна (в качестве источника которого использовался хлопчатник - Gossypium из семейства Мальвовых, произрастающий на территории Азербайджанской Республики) и приготовление на основе полученного модификата композиционного материала с наночастицами серебра, обладающего антибактериальными свойствами.

Модификация хлопкового волокна реакцией окислительного хлорфосфорилирования под действием $\mathrm{PCl}_{3}$ в присутствии $\mathrm{O}_{2}$ проводилась в соответствии с методикой, опубликованной ранее [3]. Получение наночастиц серебра и их иммобилизация in situ на поверхности модифицированного хлопкового волокна осуществлялась с использованием простого метода химического восстановления ионов серебра в присутствии боргидрида натрия [4]. Было показано, что приготовленный композиционный материал с наночастицами серебра обладает хорошими антибактериальными свойствами по отношению к Escherichia coli, Salmonella enterica, Staphylococcus aureus, а также Candida albicans.

\section{Литература}

[1] Anpilova A., Mastalygina E., Khrameeva N. and Popova A., Russian Journal of Physical Chemistry B. 2020, v. 14, N. 1, pp. 176-182.

[2] Зарубина А., Иванкин А., Кулезнев А. и Кочетков В., Лесной вестник. 2019, т. 23. № 5. c. 116-125.

[3] Akhmedov V., Maharramov A., Azizov A., Alosmanov R., Bunyad-Zadeh I. and Aliyeva S., RussianChemicalBulletin (International Edition).2019, v. 68, N. 3, pp. 1-7.

[4] Mulfinger L., Solomon S.D., Bahadory M. and all, Journal of chemical education. 2007, v. 84 (2), p. 322-325. 